\title{
Etika Pelayanan Publik (Studi Dinas Kependudukan Dan Pencatatan Sipil Kabupaten Ende)
}

\author{
Agustinus Samgar Friday Fry \\ Sekolah Tinggi Pembangunan Masyarakat (STPM) Santa Ursula \\ e-mail: samgar8586@gmail.com
}

\begin{abstract}
Abstrak
Penyelenggaraan pelayanan publik hendaknya memenuhi syarat keetisan atau sesuai dengan norma-norma etika yang berlaku. Penenelitian ini dilakukan dengan tujuan untuk mengetahui etika pelayanan publik yang dilakukan oleh birokrasi pemerintah yakni Dinas Kependudukan Catatan Sipil Kabupaten Ende dalam memberikan pelayanan kepada para pengguna jasa layanan. Terdapat banyak keluhan dari masyarakat selaku pengguna jasa layanan terhadap pelayanan administrasi kependudukan yang diberikan oleh petugas dumulai dari waktu menunggu yang sangat lama, waktu penerbitan dokumen, para petugas yang belum datang ataupun keluar pada jam kerja sampai pada kesulitan para pengguna jasa untuk bertemu dan berkomunikasi dengan petugas guna mendapatkan informasi tentang kepastian waktu dan prosedur layanan. Selain itu itu persyaratan yang secara situasional berubah menyebabkan kekecewaan dari para pengguna jasa dikarenakan sudah antri berhari-hari namun tidak mendapatkan layanan oleh karena ada persyaratan yang kurang. Konsep yang digunakan untuk menganalisa persoalan tersebut adalah konsep etika pelayanan publik yang meliputi: kejujuran, tanggungjawab, pengawasan, konsistensi sikap aparatur dan komunikasi. Hasil penelitian ini menunjukan bahwa etika pelayanan publik di dinas pencacatan sipil kabupaten ende masih perlu untuk dibenahi, hal ini ditunjukan dengan beberapa hasil temuan berdasarkan indicator etika pelayanan publik yakni kejujuran yang masih kurang, tanggungjawab yang hanya berorientasi pada tupoksi, pengawasan yang masih dalam bentuk arahan tanpa ada kontrol yang ketat dari atasan, sikap acuh petugas terhadap pengguna layanan dan komunikasi yang tidak tersampaikan secara jelas kepada pengguna layanan.
\end{abstract}

Kata kunci: Etika, Pelayanan, Publik, Kependudukan Pencatatan Sipil

\begin{abstract}
The administration of public services should meet ethical requirements or be in accordance with applicable ethical norms. This research was carried out with the aim of knowing the ethics of public services carried out by the government bureaucracy, namely Dinas Kependudukan Dan pencatatan Sipil Kabupaten Ende in providing services to service users. There are many complaints from the public as service users regarding population administration services provided by officers ranging from very long waiting times, document issuance times, officers who have not arrived or left during working hours to the difficulty of service users to meet and communicate with officers to get information about certainty of time and service procedures. In addition, the conditions that have changed situationally cause disappointment from service users because they have been queuing for days but do not get service because there are fewer requirements. The concept used to analyze this problem is the concept of public service ethics which includes: honesty, responsibility, supervision, consistency of apparatus attitudes and communication. The results of this study indicate that the ethics of public services in the civil disability service of Ende district still need to be addressed, this is indicated by several findings based on indicators of public service ethics, namely lack of honesty, responsibility that is only oriented to the main tasks and functions, supervision which is still in the form of directions. Without strict control from superiors, officers' indifference to service users and communications that are not clearly conveyed to service users.
\end{abstract}

Keywords: Ethics, Service, Public, Dinas Kependudukan 


\section{PENDAHULUAN}

Dalam penyelenggaraan pemerintahan dan pelayanan publik tidak semata-semata didasarkan pada kehendak pemerintah dan aturan-aturan teknis tetapi perlu memperhatikan kebutuhan-kebutuhan masyarakat atau pengguna jasa layanan. pelayanan publik memiliki banyak aspek seperti aspek sistem prosedur dan metode, personil, terutama ditekankan ada perilaku operator, sarana dan prasarana, dan masyarakat penerima layanan (Moenir,1995,8). Akan tetapi aspek-aspek itu justru menjadi persoalan yang belum dipenuhi oleh pemerintah dalam konteks pelayanan publik yang disebabkan oleh persoalan yang berbeda-beda sesuai dengan karakteristik dan iklim birokrasi yang ada di masing-masing daerah penyelanggaran pelayanan publik.

Laporan Ombudsman RI soal Hasil Penilaian Kepatuhan Standar Pelayanan Publik Sesuai Undang-Undang Nomor 25 Tahun 2009 Tentang Pelayanan Publik mengungkapkan kepatuhan standar pelayanan publik belum maksimal. Ini tercermin dari tingkat kepatuhan pelayanan publik di tingkat kementerian, dari standar pelayanan di 25 kementerian menunjukkan sebanyak 48 persen atau 12 kementerian masuk dalam zona kuning dengan predikat kepatuhan sedang dan 8 persen atau 2 kementerian masuk dalam zona merah dengan predikat kepatuhan rendah. Capaian itu jelas masih jauh dari target. Berdasarkan Rencana Pembangunan Jangka Menengah (RPJMN) pada 2017, seharusnya kepatuhan standar kepatuhan pelayanan publik untuk kementerian mencapai 80 persen. Sedangkan kepatuhan di lembaga negara dari 15 lembaga disurvei menunjukkan, sebanyak 13,33 persen atau 2 lembaga masuk dalam zona merah dengan predikat kepatuhan rendah, 20 persen atau 3 lembaga masuk dalam zona kuning dengan predikat kepatuhan sedang dan 66,67 persen atau 10 lembaga masuk dalam zona hijau dengan predikat kepatuhan tinggi. Realisasi ini memang jauh lebih baik dari target capaian lembaga tahun 2016 sebesar 35 persen. Untuk pemerintah provinsi, dari 33 pemerintah provinsi, sebanyak 39,39 persen atau 13 pemprov masuk dalam zona hijau dengan predikat kepatuhan tinggi. Sebanyak 39,39 persen atau 13 pemprov masuk dalam zona kuning dengan predikat kepatuhan sedang dan 21,21 persen atau 7 pemprov masuk dalam zona merah dengan predikat kepatuhan rendah. Realisasi ini masih jauh target capaian tahun 2016 sebesar 70 persen. Selain itu, dari 85 pemerintah kabupaten (pemkab) yang disurvei, menunjukkan bahwa sebanyak 29 persen atau 25 pemkab masuk dalam zona merah dengan predikat kepatuhan rendah, 53 persen atau 45 pemkab masuk dalam zona kuning dengan predikat kepatuhan sedang dan 18 persen atau 15 pemkab masuk dalam zona hijau dengan predikat kepatuhan tinggi. Terakhir, dari 85 pemerintah kota (pemkot) menunjukkan bahwa sebanyak 15 persen atau 8 pemkot masuk dalam zona merah dengan predikat kepatuhan rendah, 56 persen atau 31 pemkot masuk dalam zona kuning dengan predikat kepatuhan sedang dan 29 persen atau 16 pemkot masuk dalam zona hijau dengan predikat kepatuhan tinggi. "Hasil observasi atas ketampakan fisik atas pelayanan publik di setiap unit layanan untuk menyediakan atribut pelayanan publik menunjukkan bahwa tingkat kepatuhan pemerintah dan pemda terhadap standar pelayanan publik masih rendah (Ombudsman Republik Indonesia, 2017)

Pada tahun 2018 Kepatuhan tingkat provinsi dari 16 yang dinilai hanya 10 provinsi mendapatkan predikat zona hijau, sedangkan pada tingkat pemerintahan kabupaten dan kota dari 155 yang dinilai, sebanyak 63 kabupaten mendapat predikat zona hijau dan 18 kota juga mendapatkan predikat yang sama. Sisanya mendapat predikat kepatuhan zona kuning dan merah (Ombudsman Republik Indonesia, 2018).

Berdasarkan laporan ombudsman tersebut diatas dapa dilihat bahwa pelaksanaan penyelenggaraan publik berdasarkan asas dan standar pelayanan publik masih belum maksimal hal tersebut tentu berdampak kepada kualitas dan tingkat kepuasan pelayaan publik. Misi dari aparat birokrasi pemerintah adalah untuk memberikan pelayanan dengan sebaik-baiknya kepada masyarakat, dengan meningkatkan kualitas sumber daya manusia sehingga bisa memberikan kesejahteraan pada masyarakat banyak.

Pelayanan yang dimaksud adalah pelayanan yang terkait dengan prinsip-ᄀprinsip good governance, sebagaimana tuntutan reformasi yaitu untuk mewujudkan good governance and clean government, dalam penyelenggaraan negara yang didukung dengan 
prinsip dasar kepastian hukum, akuntabilitas, transparansi, keadilan, profesionalisme, dan demokratis seperti yang di kumandangkan oleh World Bank, UNDP, United Nation, dan beberapa lembaga Internasional lainnya.

Salah satu aspek yang menjadi permasalahan dalam pelayanan publik adalah moralitas atu etika. Dalam beberapa literatur tentang pelayanan publik, etika merupakan salah satu elemen yang sangat menentukan kepuasan publik yang dilayani sekaligus keberhasilan organisasi pelayanan publik itu sendiri. Penyelenggaraan pelayanan publik hendaknya memenuhi syarat keetisan atau sesuai dengan norma-norma etika yang berlaku. Kenyataan ini dapat dipahami, sebab fokus utama dari administrasi publik adalah menyangkut masalah-masalah kepentingan umum.

Sehubungan hal tersebut dapatlah dikatakan, etika birokrasi dalam pelayanan, apalagi kaitannya dengan penanganan urusan-urusan publik, amatlah mutlak harus diperhatikan dan digunakan sebagai landasan pelaksanaannya. Dengan demikian, diharapkan pelaksanaan penanganan masalah urusan publik oleh aparat birokrasi benarbenar sesuai dengan etika yang berlaku serta memiliki orientasi publik. Dengan kata lain, norma etika dalam proses penyelenggaraan pelayanan publik benar-benar diterapkan. Penerapan etika birokrasi dalam proses pelayanan publik pada kantor pemerintah dengan pegawai negeri sebagai aparat publiknya, memang sudah selayaknya dilaksanakan, karena esensi dari pemberian pelayanan adalah memberikan kepastian dan kepuasan kepada pihak yang dilayani (pengguna jasa layanan). Etika dalam pelayanan publik diperlukan sebagai bentuk adanya sikap tanggap dari aparat birokrasi terhadap kepentingan masyarakat pengguna jasa. Kepentingan pengguna jasa harus di tempatkan sebagai tujuan utama. Melalui prinsip pelayanan tersebut, diharapkan tidak terjadi diskriminasi dan bersikap ramah dalam memberi pelayanan, sehingga pengguna jasa merasa memperoleh pelayanan yang sebaik-baiknya. Jika kondisi pelayanan demikian diciptakan, etika pelayanan publik dapat berjalan sesuai dengan misi aparat birokrasi dan tuntutan masyarakat pengguna jasa (Dwiyanto, 2000). Berdasarkan uraian tersebut, dapat dikatakan pengembangan etika dalam pelayanan publik sangatlah perlu dijadikan dasar bertindak oleh setiap aparat dalam menjalankan fungsi sebagai pelayan publik.

Setiap pemerintah daerah memiliki ciri khas persoalan yang berbeda-beda. Hal ini, dapat dilihat pada salah satu daerah di Indonesia, yaitu Pemerintah Kabupaten Ende yakni dalam hal persoalan kependudukan.

Sebagai salah satu Organisasi Pelaksana Daerah, Dinas Kependudukan dan Catatan Sipil Kabupaten Ende merupakan salah satu dinas yang langsung bersetuhan dengan masyarakat dalam pelayanan publik dan paling sering di perbincangkan terkait dengan pelayanannya. Berkaitan dengan etika pelayanan publik dalam prakteknya berdasarkan hasil pengamatan, masih terdapat adanya keluhan masyarakat mengenai proses pengurusan KTP dan Penyesuaian data Kartu Keluaraga. Dari hasil pengamatan dan pengakuan pegguna jasa layanan bahwa sampai saat ini ada beberapa penduduk yang belum meiliki KTP sedangkan proses pengurusan adminsitrasinya sudah dilakukan dari bulan dan bahkan tahun sebelumnya.

Selain itu, pelayanan dikantor dinas kependudukan dan catatan sipil Kabupaten Ende berdasarkan hasil pengamatan terlihat bahwa pintu ruangan kantor ditutup padahal terdapat antrian panjang masyarakat didepan pintu yang membutuhkan pelayanan. Alasan untuk menutup pintu tidak jelas apakah karena dalam ruangan terdapat pendingin ruangan atau karena tidak ingin terganggu dengan pemandangan antrian panjang masyarakat yang membutuhkan pelayanan.

Demikian halnya dengan pengurusan ulang dan singkronisasi dokumen Kartu Keluarga dengan KTP atau mengurus ulang Kartu Keluarga yang hilang, Masyarakat dihadapkan dengan proses perosedural yang cukup panjang dan terkesan rumit, sehingga menimbulkan kebingungan dan kelelahan menunggu dari pengguna layanan atau masyarakat. Selain itu ketika ada keluhan nomor induk KTP dan nomor Kartu Keluarga yang tidak singkron masyarakat diminta untuk menghubungi sendiri administrator melalui alat komunikasi genggam. 
Dalam situasi semacam di atas menunjukan betapa pelayanan publik menjadi suatu persoalan yang cukup serius untuk di tinjau baik dari proses penyelenggaran maupun soal keetisan dalam proses pelayanan. persoalan birokrasi disisi lain adalah cenderung akan melayani pengguna jasa sesuai dengan prosedur yang ada dan aturan-aturan situasional yang dilakukan kendatipun mereka sadar bahwa hal semacam itu tidak relevan dengan kebutuhan dan situasi yang berkembang dalam masyarakat. Kondisi seperti ini yang membuat masyarakat kecewa terhadap pelayanan publik. Bahkan, tidak jarang konflik yang terjadi antara masyarakat dengan birokrasi karena orientasi yang berlebihan terhadap peraturan dan prosedur.

Berdasarakan uraian kodisi ideal dan situasi masalah yang telah diuraiakan diatas maka penelitian ini akan dilakukan dengan judul penelitian Etika Pelayanan Publik (Studi Di Dinas Kependudukan Dan Pencatatan Sipil Kabupaten Ende)

Etika birokrasi dalam pelayanan publik sangat penting untuk dilaksanakan dengan didukung oleh faktor-faktor lain, seperti konsistensi aparat birokrasi yang berdasarkan etika dalam menegakkan etika pelayanan publik karena akan menentukan baik buruknya kualitas pelayanan yang diberikan kepada masyarakat, di samping adanya fungsi pengawasan yang baik untuk mencegah secara dini tindakan-tindakan aparat yang menyimpang dari etika. Selanjutnya, dalam mensosialisasikan aturan yang telah disepakati bersama proses komuniksai yang efektif sangat penting dilakukan, dengan jalan pemberian informasi yang jelas dan benar kepada stakeholders, sehingga aturan tersebut dapat dipahami oleh para stakeholders. Kepuasan masyarakat tentunya menjadi dambaan seluruh lapisan masyarakat pengguna jasa dan hal itu akan dapat terwujud apabila benar-benar aparat pelaksana dapat menerapkan etika birokrasi dalam pelayanan publik.

\section{METODE PENELITIAN}

Metode penelitian yang digunakan dalam penelitian ini adalah metode deskriptif kualitatif. Menurut Mardalis $(1989,26)$ metode penelitian ini bertujuan untuk mendiskripsikan, mencatat, menganalisa dan menginterpretasikan kondisi-kondisi yang terjadi. Lebih lanjut Afiff $(1998,4)$ menyatakan bahwa metode kualitatif sebagai prosedur penelitian yang menghasilkan data deskriptif dari orang-orang atau masalah sosial yang diamati.

Sehubungan dengan pejelasan tersebut diatas maka penelitian Etika Pelayanan Publik (Studi Di Dinas Kependudukan Dan Pencatatan Sipil Kabupaten Ende) merupakan penelitian analisis deskriptif yang penelitian dilakukan dengan cara mengumpulkan data berdasrakan fakta-fakta yang terjadi dilapangan dengan menggunakan teknik pengumpulan data yakni wawanacara, observasi dan dokumntasi, kemudian data - data tersebut dipilah berdsarakan relevasinya dengan indikator-indikator penelitian tanpa merubah fakta yang terjadi dilapangan kemudian menganalisa fakta-fakta tersebut dengan menggunakan konsep etika pelayanan publik sebagai dasar konsep untuk menganalisa personal yang terjadi dilapangan.

\section{HASIL DAN PEMBAHASAN \\ Etika Pelayanan Publik (Studi Di Dinas Kependudukan dan Pencatatan Sipil Kabupaten Ende)}

Tata rcara pelayanan dalam etika pelayanan pulik tidak hanya berdasarkan kebiasaan-kebiasaan, namun juga mengacu pada nilai-nilai dan norma-norma etika sebagai pedoman dalam mengatur tingkah laku aparatur yang dianggap baik. Etika birokrasi dalam pelayanan publik harus mampu dan bisa memberikan pelayanan yang sifatnya lebih mengutamakan kepentingan umum di atas kepentingan pribadi, kelompok, dan organisasinya.

Etika pelayanan publik dalam peneltian ini, dilihat dari sudut apakah seorang aparat birokrasi telah menjalankan tugasnya sebagai seorang abdi masyarakat. Untuk itu, aparat birokrasi dalam pemberian pelayanan kepada publik harus memperhatikan hak-hak pengguna jasa layanan untuk mendapatkan pelayanan melalui prosedur dan ketentuan yang dirumuskan dalam indikator etika pelayanan publik yakni Kejujuran, Tanggung jawab, 
pengawasan Konsistensi Aparat Birokrasi dan Komunikasi. Tindakan dari aparat birokrasi sebagai public service yang memiliki etika dapat tercermin dari sikap sopan dan ramah, inklas, dan adil melayani masyarakat.

\section{Kejujuran}

Kejujuran adalah sifat yang melekat pda diri seseorang dan merupakan hal penting untuk dilakukan dalam kehidupan sehari-hari. Menurut Kesuma, dkk (2012:16) kejujuran diartikan sebagai suatu keputusan untuk mengungkapkan perasaannya kata-kata atau perbuatannya bahwa realitas yang ada tidak dimanipulasi dengan cara berbohong atau meniru orang lain untuk keuntungan dirinya.

Kejujuran dalam etika pelayanan publik sperti yang diungkapkan oleh Dwiyanto menjadi salah satu ukuran yang penting untuk dapat melihat sejauh mana etika perilaku aparat birokrasi dalam memberikan pelayanan. Seorang aparat birokrasi dapat dikatakan beretika jika segala perkataan dan tidandakan tidak melenceng dari apa yang seharusnya. Sehubungan dengan hal ini jika dikaitkan dengan penelitian yang telah dilakukan di Dinas Catatan Dan Kependudukan Sipil Kabupaten Ende bahwa sikap kejujuran pegawai masih berlaku kepada atasan sedangkan kepada pengguna jasa masih ada manipulasi informasi dengan mengatakan sesuatu yang lain dari apa yang sebenarnya terjadi. Hal ini dapat disebabkan oleh karena ketidaktahuan atau demi menguntungkan diri sendiri agar tidak disalahkan dalam melaksanakan pekerjaan. Selain itu perilaku untuk melakukan suatu pekerjaan secara tulus tidak nampak dalam diri pegawai. Terlihat bahwa pegwai nampak masa bodoh sibuk dengan urusannya dan membiarkan masyarakat pengguna jasa layanan menunggu di ruang tunggu tanpa menanyakan sesuau yang bias dilakukan untuk membantu atau meberikan pelyanan kepada pengguna jasa atau masyarakat.

\section{Tangung Jawab}

Tanggung jawab menurut Widodo, 2001: 270-271 merupakan bentuk responsif yang lebih mengarah pada daya tanggap dan cepat menanggapi apa yang menjadi masalah, kebutuhan dalam aspirasi masyarakat yang dilayani dan ketepatan waktu yang mengandung arti pelaksanaan pelayanan masyarakat dapat diselesaikan dalam kurun waktu yang telah ditentukan.

Sehubungan dengan hal tersebut diatas jika dikaitkan dengan penelitian yang telah dilakukan di Dinas Kependudukan Dan Pencatatan Sipil Kabupaten Ende ditemukan bahwa ada beberapa penyebab yang menjadi terhambtanya proses pelayanan yang kemudian dapat berdampak kepada ketepatan waktu penyelesaian pelayanan salah satunya yakni rusaknya saran prsasarana. Sikap demikian merupakan bentuk pelemparan tangunggjawab dan kecenderungan untuk menyalahkan suatu hal yang lain sebagai bentuk pembenaran diri pada pelaksanaan tugas.

Etika pelayanan publik berdasarkan konsepnya adalah mengenai moral perilaku aparat birokrasi dalam melaksanakan pekerjaannya sehari-hari. Salah satunya adalah ditunjukannya tanggung jawab soerang aparatur dengan menanggapi suatu persoalan dengan cepat dan menyelesaikan suatu pekerjaan dengan penyelesaian waktu yang efektik. Hal ini mengandung pengertian bahwa dalam melaksanakan suatu pekerjaan seorang aparatur tidak cenderung menyalahkan suatu persoalan yang lain sebagai bentuk pertanggungjawabanya. Bahwa seorang pengguna layanan tidak pantas untuk diberitahu alasan bahwa karena peralatan rusak. Dengan mengatakan bahwa alat rusak dapat dijadikan sebagai alasan dari aparatur untuk membenarkan tidakan keterlambatan atau ketidaktepatan waktu dalam melakukan proses pelayanan.

Selain itu bentuk pertanggungjawaban yang cenderung dilakukan oleh aparatur Dinas Kependudukan Dan Pencatatan Sipil Kabupaten Ende adalah dalam bentuk peratnggungjawaban kepada atasan yang mana idealnya bentuk pertangungjawab itu selain kepada atasan adalah tangungjawabnya kepada pengguna layanan jasa dengan memberiakan sikap responsive dalam menyelesaikan persolan yang dihadapi oleh pengguna jasa. 
Salah satu yang menajdi persoalan terkait dengan pertangungjawaban adalah kesadaran pegawai akan kebutuhan pengguna jasa. Sikap dan perilaku yang lebih menekakan bekerja berdsarkan tuposki dan aturan cenderung mengabaikan hak - hak pengguna jasa, bahwa masyarakat atau pengguna jasa butuh untuk dilayani atau dipenuhi kebutuhan terkait urusan-urusan dokumen administrasi kependudukan. Akan tetapi kepekaan atau kesadaran seperti harus memberikan pelayanan sesuai dengan kebutuhan pelanggan atau pengguna jasa masih belum terlalu nampak dalam pelayanan.

\section{Komunikasi}

Komunikasi merupakan aspek yang sangat penting dalam pelayanan publik. Dalam praktek pelayanan publik kegiatan komunikasi yang sangat kompleks dan melibatkan berbagai elemen karena dalam pelayanan publik dalam suatu oraganisasi memiliki derajat homogenitas atau keragaman yang tinggi. Komunikasi yang cenderung terjadi dalam suatu organisasi pelyanan public adalah komunkasi yang terjadi antara atasan dan bawahan ataupun sebaliknya atau komunkasi anatara aparat birokrasi dengan pengguna jasa.

Komunikasi Menurut Komarudin (2000:76) Mengemukakan bahwa Komunikasi merupakan proses menyampaikan pikiran, informasi, peraturan atau instruksi dengan suatu cara tertentu agar penerimanya memahami pesan yang dietrimannya. Dalam pelayanan publik suatu informasi yang diberikan kepada seseorang atau pengguna jasa harus efektif artinya suatu infromasi mudah untuk dipahami dan mudah untuk diakses.

Berkaitan denga hal tersebut diatas jika dikaitkan dengan komunikasi dalam hubungannya dengan pelayanan publik yang terjadi di Dinas Kependudukan Dan Pencatatan Sipil Kabupaten Ende berdasarkan hasil penelitian ditemukan bahwa kegiatan komunkasi dalam bentuk sosialisasi kepada masyarakat telah dilakukan dengan berkerja sama dengan organisasi lain yakni organisasi kelurahan dan desa untuk memperpendek jarak dan rantai birokrasi dalam pelayanan administrasi kependudukan serta mengurangi besarnya jumlah masyarakat yang sering datang langsung ke kantor Dinas Kependudukan Dan Pencatatan Sipil Kabupaten Ende untuk mendapatkan pelayanan administrasi kependudukan. Sosilisasi ini tidak membuahkan hasil yang maksimal karena masih banyak masyarakat yang masih datang dan menanyakan informasi kepada Dinas Kependudukan Dan Pencatatan Sipil Kabupaten Ende secara langsung. Selain itu pemberian informasi yang mudah dipahami oleh pengguna jasa belum dilakukan secara baik hal ini ditunjukan dengan tampilan infromasi yang dimuat dipapan pengumuman masih menujukan atauran-aturan yang oleh pengguna jasa yang alin sulit untuk dipahami, tidak ditujunkan bagan laur sebagai pentujuk kepengurusan layanan menjadi salah satu hal yang bernilai kurang. Selain itu tidak tersedianya saran website sebagi bagian komunkasi yang efektif atau mudah diakses menjadikan penlaian terhadap kurangnya niatan dari Dinas Kependudukan Dan Pencatatan Sipil Kabupaten Ende untuk memebrikan layanan yang mudah diakses.

Dari hasil analisis tentang komunikasi di atas, disimpulkan komunikasi belum berjalan dengan efektif dalam artian tidak terjadi komunikasi yang sifatnya dua arah dalam mensosialisasikan aturan yang ada di Dinas tersebut, jika dilihat dari rincian $\neg$ yang digunakan dalam penelitian ini. Hal ini, terjadi karena; pertama, upaya yang telah dilakukan oleh instansi tersebut dalam mensosialisasikan aturan organisasi menjadi mubasir karena informasi yang disampaikan tidak mendapat respon dari masyarakat; kedua, sarana atau media yang digunakan dalam penyampaian informasi juga tidak efektif, dalam artian banyak masyarakat tidak memahami makna dari informasi tersebut; ketiga, luasnya jangkauan wilayah pelayanan, jumlah penduduk yang dilayani tidak seimbang dengan jumlah pegawai yang dimiliki Dinas Kependudukan dan Catatan Sipil, sehingga akhirnya tidak semua masyarakat pedesaan yang ada di Kabupaten Ende terjangkau oleh program sosialisasi tersebut.

Komunikasi sangat penting dalam sebuah organisasi, karena tanpa komunikasi kegiatan organisasi tidak akan bisa berjalan dengan lancar. Sekarang masyarakat menuntut organisasi bekerja dengan tempo yang semakin tinggi untuk merealisasikan 
program-programnya, anggota organisasi harus peka dan tanggap dengan sikap proaktif terhadap perubahan dalam nilai-nilai sosial, komunikasi yang efektif dan kerjasama ditumbuhkan dan dikembangkan. Selain itu kominikasi anata pegawai di organisasi DUCAPIL ende masih bersifat hirkasi artinya komunikasi yang dilakukan masih bersifatr instruksi yang berkaitan dengan tupoksi belum sampai kepada solusi tentang bagaimana memberikan pelayanan yang lebih baik kepada pengguna jasa atau masyarakat.

\section{Konsistensi Perilaku Aparat Birokrasi}

Konsistensi merupakan kesesuaian dan ketepatan tindakan aparat dalam proses pelayanan publik. Artinya sebagai pelayan publik dalam proses penyelenggaraan pelayanan publik aparat birokrasi yang memiliki konsistensi tercermin dari kesesuaian aparat tersebut untuk bertindak.

Sehubungan dengan hal tersebt diatas dan dikaitkan dengan hasil penelitian dapat dijelaskan bahwa terlihat banyak pegawai memiliki semangat kerja dan ketaatan dalam melakukan pekerjaan sesuai aturan, namun ketaatan dan semangat pegawai tersebut nampak jika ada pengawasan dari pimpinan. Dalam artian pekerjaan yang dilakukan cenderung merupakan tekanan baik oleh atasan maupun aturan yang ada, bukan muncul dari kemauan sendiri. Selain itu munculnya tanggung jawab dari setiap aparat birokrasi lebih kepada penugasan yang diberikan. Artinya konsistensi aparat birokrasi masih kurang nampak dari adanya kesadaran sendiri dalam tugas, karena perasaan untuk ikut memiliki belum tumbuh, loyalitas yang diberikan bukan pada organsiasi tapi lebih kepada atasan yang memberikan tugas. Untuk itu, mereka memandang pekerjaan yang dilakukan atas ikatan aturan.

Kesesuaian tindakan yang dimaksud adalah tindakan yang dilakukan berdasarkan atas norma-norma etika yang telah disepakati bersama. Apabila etika dapat dilaksanakan secara konsisten, maka dapat diharapkan bahwa di antara pejabat publik akan tumbuh semangat humanisme untuk memberikan pelayanan bagi masyarakat luas dengan kesetiaan kepada etika yang utuh. Dalam keadaan seperti itu setiap program organisasi beserta implementasinya akan berjalan sesuai dengan keinginan bersama. Lebih dari itu aparat birokrasi akan mendapat kepuasan maksimal dari pekerjaannya karena mereka bekerja tidak setengah-setengah, begitu pula masyarakat yang dilayani mereka juga akan merasa puas karena pelayanan yang didapatkan tidak ada pengorbanan yang sia $\neg$-sia. Jika merujuk pada pendapat Toha bahwa ada tiga dimensi yang menentukan konsistensi aparatur yakni dimensi konsep, dimensi teknis dan dimensi manusia, maka dimensi konsep masih menjadi persoalan dalam konstensi aparat di Dinas Kependudukan Dan Catatan Sipil Kebupaten Ende karena hampir sebagian besar pegawai bekerja berdasarkan hal-hal teknis tanpa disertakan dengan konsep yang jelas sehingga menyebabkan banyak pelayanan yang tertunda sampai berhari-hari.

\section{Pengawasan}

Berdasarkan hasil penelitian yang dilakukan tentang mekanisme pengawasan dapat disimpulkan bahwa mekanisme pengawasan yang berfungsi sebagai antisipasi terhadap adanya tindakan-tindakan penyimpangan dalam penegakan etika pelayanan di Dinas tersebut dapat dinilai sudah berjalan berjalan namun masih terkendala dengan beberap hal. Pertama, berkaitan pengawasan yang dilakukan oleh atasan terhadap bawahan pelaksanaannya monoton dan dilakukan dalam bentuk arahan pada saat apel namun minim melakukan monitoring; Kedua, tidak adanya pengawasan dari bawahan dalam bentuk memberi saran atau masukan kepada atasan karena didasarkan oleh rasa keengganan menjadikan fungsi pengawasan pada organisasi ini lemah.

Berhasil tidaknya etika dalam pelayanan publik mencapai tujuan yang telah ditetapkan sangat berhubungan dengan pengawasan. Mekanisme pengawasan merupakan sistem dalam mengantisipasi terjadinya tindakan-tindakan menyimpang terhadap tujuan organisasi. Dari penjelasan tersebut dapat dikatakan mekanisme pengawasan merupakan salah satu faktor yang memiliki hubungan dengan etika pelayanan publik. Sebab baik buruknya mekanisme pengawasan yang dilakukan akan sangat berdampak bagi penerapan etika dalam pelayanan publik. 
Dalam kerangka meningkatkan etika birokrasi dalam pelayanan publik mekanisme pengawasan yang dilakukan dengan baik akan dapat mengantispasi terjadinya tindakantindakan menyimpang atas pelaksanaan rencana yang telah ditetapkan. Etika pelayanan publik tidak akan bisa efektif kalau mekaniseme pengawasan tidak berjalan dengan baik. Karena pengawasan atas penyimpangan dari rencana dapat dilakukan tindakan korektif, dan hasilnya dapat dijadikan umpan balik untuk memperbaiki proses pelayanan pada masa berikutnya. Sehubungan dengan hal tersebut, pengawasan menjadi penting untuk membantu meningkatkan dan mencegah terulangnya kesalahan yang diperbuat, sehingga akibat yang lebih buruk atas kekhilafan dan kesalahan dapat dihindarkan. Pengawasan bukan kegiatan yang berusaha mencari kesalahan yang diperbuat seseorang, melainkan ditujukan untuk menemukan secara dini kesalahan-kesalahan atau penyimpangan-penyimpangan, sehingga dapat segera diadakan perbaikan dan pelurusan kembali. Untuk itu pentingnya mekanisme pengawasan dalam melaksanakan tugas pokok, fungsi dan wewenang terutama dalam menjalankan etika pelayanan publik dengan baik adalah untuk melakukan penyempurnaan prosedur, baik yang bersifat preventif, pengendalian, maupun represif. Berjalannya mekanisme pengawasan dengan baik akan dapat mewujudkan pemerintahan yang bersih dan berwibawa.

\section{SIMPULAN}

Berdasarkan pada hasil penelitian dan analisis etika pelayanan publik dari indikatornya, maka etika pelayanan publik di Dinas Kependudukan dan Catatan Sipil Kabupaten Ende dapat disimpulkan bahwa: Etika birokrasi dalam pelayanan publik di Dinas Kependudukan dan Catatan Sipil Kabupaten Ende, sebagaimana ditunjukkan oleh penelitian ini masih masih perlu ditingkatkan. Dilihat dari indikator-indikator dalam penelitian ini etika birokrasi dalam pelayanan publik masih sangat jauh dari yang diharapkan. Kurangnya etika birokrasi dalam pelayanan publik dalam penelitian ini, ditentukan oleh beberapa faktor yaitu: Kejujuran, Tanggung jawab, Komunikasi, Konsistensi dan Pengawasan.

\section{DAFTAR PUSTAKA}

Dwiyanto Agus, Partini, Ratminto, Wicaksono Bambang, Tamtiari Wini, Kusumasari Bevaola, dan Nuh Muhamad, 2002, Reformasi Birokrasi Publik Di Indonesia, Pusat Studi Kependudukan dan Kebijakan (PSKK), UGM., Yogyakarta.

Effendi, Sofian \& Singarimbun Masri, 1989, Metode Penelitian Survai, Lembaga Penelitian, Pendidikan dan Penerangan Ekonomi dan Sosial (LP3ES), Jakarta.

Faisal, Sanapiah, 2001, Format-Format Penelitian Sosial, Raja Grafindo Persada, Jakarta.

---- 1997, Organisasi: Perilaku Struktur dan Proses, Erlangga, Jakarta.

Indrawijaya, I. Adam, 2000, Perilaku Organisasi, Sinar Baru Algensindo, Bandung.

Invancevich, John M, and Matteson, Michael T, 1999, Organizational Behavior and Management, Irwin Mc Graw-Hil, Boston, USA.

Kartasasmita, Ginandjar, 1997, Administrasi Pembangunan: Pekembangan Pemikiran dan Praktiknya di Indonesia, LP3ES, Jakarta.

Kesuma, Dharma, 2012, Pendidikan Karakter Kajian Teori Dan Praktek, Bandung: PT Raja Grafindo Persada

Kumorotomo, Wahyudi, 1992, Etika administrasi Negara, Rajawali Pers, Jakarta.

Mulyana, Dedy, 2003, Ilmu Komunikasi Suatu Pengantar, PT. Remaja Rosdakarya, Bandung.

Moenir, H.A.S, 1995, Manajemen Pelyanan Umum di Indonesia, PT. Bumi Aksara, Jakarta.

Moleong, Lexy J, 1989, Metode Penelitian Kualitatif, Remaja Rosdakarya, Bandung.

Musatari, Mohamad, 2011, Nilai Karakter, Yogyakarta: LaksBang Presindo

Ndraha, Taliziduhu, 2003, Kybernology (Ilmu Pemerintahan Baru), Rineka Cipta, Jakarta.

Nawawi, Hadari, 2003, Metode Penelitian Bidang Sosial, Gadjah Mada University Press, Yogyakarta. 
Sulistiyani, Ambar Teguh dan Rosidah, 2003, Manajemen Sumber Daya Manusia; Konsep, Teori dan Konteks Organisasi Publik, Graha IImu, Bandung.

Siagian, Sondang P, 1988, Organsiasi, Kepemimpinan \& Perilaku Administrasi,

CV. Haji Masagung, Jakarta.

Syafie, Inu Kencana, dkk, 1999, Ilmu Administrasi Publik, Rineka Cipta, Jakarta.

Thoha, Miftah, 1995, Birokrasi Indonesia Dalam Era Globalisasi, Pusdiklat Pegawai Depdikbud, Sawangan-Bogor. Yogyakarta.

Persada, Jakarta.

Tjokrowinoto, Moelyarto, 2001, Birokrasi dalam Polemik, Pustaka Pelajar, Jakarta.

Utomo, Warsito, 2002, Dinamika Administrasi Publik Analisis Empiris Seputar Isu-Isu Kontemporer dalam Administrasi Publik, Kerjasama dengan MAP, UGM, Yogyakarta.

Widodo, Joko, 2001, Good Governance, Telaah dari Dimensi Akuntabilitas dan Kontrol Birokrasi Pada Era Desentralisasi dan Otonomi Daerah, Insan Cendekia, Surabaya.

Yin, Robert K, 2003, Studi Kasus (Desain dan Metode), Rajawali Pers, Jakarta.

Dwiyanto, Agus, 2011, Redifinisi Administrasi Publik, Hand Out Kuliah MAP UGM, Yogyakarta.

Keban, Yeremias T, 1994, Pengantar Aministrasi Publik, Program MAP UGM, Yogyakarta.

--------, 2011, Metode Penelitian Kualitatif, Hand Out Kuliah Program Studi IImu Administrasi Negara, Program Pasca Sarjana UGM, Yogyakarta.

Lakip Dinas Kependudukan Dan Pencatatan SipilTahun 2019

Renstra Dinas Kependudukan Dan Pencatatan Sipil Tahun 2014-2019

Renja Dinas Kependudukan Dan Pencatatan Sipil Tahun 2018 dan 2019

Salinan Undang-Undang No. 23 Tahun 2014 Tentang Pemerintah Daerah

Salianan Undang-Undang No 33 Tahun 2004 Tentang Perimbangan Keuangan Pemerintah Dan Daerah

Salinan Undang-Undang No. 25 Tahun 2009 Tentang Pelayanan Publik

Salinan Peraturan Pemerintah No 42 Tahun 2004 Tentang Etika Pelayanan Publik. 